MAREK HENDRYKOWSKI

Uniwersytet im. Adama Mickiewicza

\title{
Nowy dokument historyczny
}

Film montażowy, nazywany również niekiedy filmem z filmów (ang. compilation, found footage film) od pewnego czasu cieszy się nadspodziewanie żywym zainteresowaniem, zarówno wśród realizatorów, jak i publiczności. Stała się rzecz do niedawna niemal nie do pomyślenia. Filmy montażowe nowej generacji - wzbogacone technologicznie o kolor, scenografię dźwiękową i efekty wizualne - nie tylko wchodzą do repertuaru multipleksów, ale osiągają w nich zaskakująco dobre wyniki frekwencyjne, czego najlepszym jak dotąd polskim przykładem jest niedawny sukces Powstania warszawskiego (2014).

Czy można stworzyć własną oryginalną koncepcję dokumentu filmowego o tematyce historycznej? Spróbujmy zaproponować założenia takiego projektu, otwierając możliwość merytorycznej dyskusji i potwierdzając dzięki niej sensowność dalszych warsztatowych poszukiwań. W generalnym zarysie projekt poniższy - odmienny od tych, z którymi na ogół mamy dzisiaj do czynienia w praktyce realizacyjnej zmierza do stworzenia innej niż dotychczasowa, niemal nieobecnej w polskim dokumencie, zsubiektywizowanej formuły montażowego filmu historycznego.

Subiektywizacja, o której tu mowa, jest pojęciem niejednoznacznym. Jednym $z$ jej aspektów pozostaje dążenie nadawcy przekazu do osiągnięcia z góry narzuconego sensu. Materiał filmowy użyty w taki sposób degraduje się w funkcji ilustracji apriorycznie założonych przez autora znaczeń. Historia „pod tezę” staje się w konsekwencji serią - zamienionych doraźnie w ekranową ilustrację - obrazów pozbawionych pierwotnego znaczenia. Nie jest ona obiektem odkrywania i interpretacji, lecz przedmiotem semantycznej manipulacji wykorzystanymi w filmie materiałami. „Fakty” historyczne zostają w nim arbitralnie wykreowane i zarazem „poświadczone” za pomocą ruchomych obrazów, bez możliwości odkrycia i wyjaśnienia złożonego sensu wydarzeń, o których mowa w filmie[1].

Mając na uwadze czynnik tak pojmowanego „subiektywizmu", mówimy nie tyle o czyimś indywidualnym punkcie widzenia, ile o z góry powziętej „użyteczności” wymowy wszelkich ukazanych na ekranie faktów historycznych. Nie wolno zapominać, iż wiele klasycznych dokumentów montażowych (przykładowo: Upadek dynastii

[1] [Adres bibliograficzny zdradzał tożsamość auto-

ra - dop. redaktorzy]. 
Romanowów, 1927; Wielka droga, 1927 i Rosja Mikołaja II i Lew Tołstoj, 1928, których reżyserem była Esfira Szub; Mein Kampf, 1960, Erwina Leisera; Umrzeć w Madrycie, 1962, Frédéricka Rossifa; Zwyczajny faszyzm, 1965, Michaiła Romma) powstało niegdyś dla konkretnych celów politycznych.

Propagandowa wymowa wymienionych wyżej, a także bardzo wielu innych, filmów z filmów znalazła swój wyraz w określonym doborze, zamierzonym zestawieniu i szczególnej konstrukcji montażowej wszelkich scen i ujęć wykorzystanych przy ich tworzeniu. Obrazy zawarte $\mathrm{w}$ tych materiałach w momencie ich wykorzystania niosły z sobą odmienny, a niekiedy wręcz diametralnie różny, sens pierwotny. Wmontowane i przemyślnie wpisane w nowy porządek - pełniły rolę dowolnie modyfikowanych za pomocą montażu przytoczeń „cudzego punktu widzenia” i „cudzej mowy”, znacząc odtąd co innego (a bywało niejednokrotnie, iż całkiem co innego) niż uprzednio.

Zabiegi znaczeniowe tego rodzaju, polegające na nadawaniu użytemu materiałowi nowego sensu, same przez się nie stanowią niczego nadzwyczajnego. Dają one bowiem o sobie znać w każdym bez wyjątku filmie montażowym i są zabiegami nieodzownymi. Ingerencje semantyczne, do których za każdym razem dochodzi, polegają na arbitralnie subiektywnym zdekonstruowaniu sensu poprzedniego i zastąpieniu go nową - niejednokrotnie z gruntu inną, przeciwstawną wymową. Tworzy się ona za przyczyną jego reakcji w zetknięciu z mikro- i makrokontekstem: w wyniku wmontowania w układ nowej całości.

Powtórzmy raz jeszcze: owa gra $z$ „cudzym obrazem” i z „cudzym spojrzeniem” nie jest w filmie montażowym czymś nadzwyczajnym, okazjonalnym i występującym fakultatywnie. Wprost przeciwnie, pojawia się ona stale i okazuje się być nieodzowną koniecznością jako obligatoryjny aspekt filmowej kreacji. W kinie, telewizji i nowych mediach mamy z nią do czynienia na każdym kroku. W przekazach złożonych $\mathrm{z}$ ruchomych obrazów stanowi zjawisko stale obecne: jako powszechnie stosowany sposób konstruowania struktury semantycznej danego utworu.

Problem komunikacyjny, jakim są tego typu operacje, polega na czym innym i czymś więcej niż na samym ich występowaniu. Ingerencja ingerencji nierówna. Distinguendum est... Samo operowanie materiałem zdjęciowym zmierzające do wydobycia tkwiących w nim głębszych znaczeń, względnie korekty znaczeń dotychczasowych, nie jest bynajmniej równoznaczne $\mathrm{z}$ manipulacją. Manipulacja różni się od zwykłych operacji znaczeniotwórczych tym, iż całkowicie zmienia (czytaj również: przeinacza) wyjściowy sens materiału, by arbitralnie narzucić sens pożądany przez nadawcę.

W filmie montażowym - nawet takim, który dąży do obiektywności przekazu - nie da się wykluczyć obecności określonego autorskiego przesłania, skoro jego celem jest wykreowanie sensownej całości wyższego rzędu. Każda operacja montażowa dokonywana na ruchomych obrazach pociąga za sobą użycie określonego repertuaru chwytów narracyjnych, środków stylistycznych, figur składniowych, 
ergo - zaangażowania określonych środków wyrazu. Czym innym jest jednak autorskie przesłanie jako rezultat serii dokonanych przez twórcę operacji semantycznych, a czymś całkiem innym - manipulowanie przez realizatora montowanym materiałem.

Istniała, istnieje i zawsze będzie istnieć zasadnicza różnica między rzetelnym komunikowaniem o przeszłości a narzuconą przez nadawcę przekazu i użytkownika tych taśm demagogią, która tę przeszłość przeinacza i falsyfikuje. Nie ma to nic wspólnego z naturalną odmiennością alternatywnych punktów widzenia autorów dwóch różnych przekazów tyczących tego samego.

Mowa jest o przepastnej różnicy operowania materiałem kinematograficznym, jaka zachodzi między działaniem godziwym (operacje montażowe) i niegodziwym (manipulacje montażem). Różnica ta dotyczy również poszerzającego się stale zakresu wszelkiego rodzaju autorskich ingerencji $\mathrm{w}$ materiał zdjęciowy $\mathrm{z}$ epoki - zabiegów polegających na łączeniu go $\mathrm{z}$ różnymi formami: reinscenizacji, wstawek aktorskich, partii animowanych, obróbki montażowej, przetworzeń komputerowych etc.

Właściwie pojęty dokument historyczny dopuszcza ich użycie w filmie, ale nie dopuszcza manipulowania fikcją, która zrównuje nadawanie sensu z manipulowaniem przekazem. Cel z całą pewnością nie uświęca w tym przypadku środków. Kryterium rozróżnienia pomiędzy jednym a drugim jest proste: ekranowe zmyślenie w żadnym razie nie może rozmijać się z prawdą, do której poznania dążą autor i widz. Właśnie tej istotnej granicy wiarygodności nie wolno przekroczyć nadawcy danego przekazu.

Od lat 20. do chwili obecnej film z filmów (zwany również montażowym lub zestawnym) przeszedł długą drogę ewolucji, która każe współczesnemu badaczowi całkiem inaczej spojrzeć na problematykę subiektywizacji ekranowych przedstawień historii w filmie montażowym. Nieporównanie wyższy stopień ekranowej inwencji i finezji osiągnęło w nim na przykład posługiwanie się: inscenizacją, scenografią dźwiękową, animacją czy wstawkami z udziałem aktorów. Zabiegi te, niewątpliwie wydobywające umowność i podmiotowość przekazu, należą dzisiaj do standardowych. Znakomite osiągnięcia na tym polu notuje dokument polski, by przywołać tylko: 45-89 Marcela Łozińskiego (1990), Z Kroniki Auschwitz Michała Bukojemskiego (2004), Po-lin. Okruchy pamięci Jolanty Dylewskiej (2008), Radegast Borysa Lankosza (2008) czy Cudze listy Macieja Drygasa (2010).

Współczesna poszerzona formuła filmu montażowego, o której tu mowa, jest jedną z wielu możliwych, a nie czymś „gotowym”, raz na zawsze ustalonym i powszechnie obowiązującym. Jej zewnętrznym wyróżnikiem pozostaje szeroki udział materiału inscenizowanego, włącznie z zabiegami dramatyzacji i fabularyzacji. Czy jest to jednak wyróżnik podstawowy dla charakterystyki filmu montażowego nowej generacji? I czy musi on każdorazowo występować jako coś nieodzownego?

Współczesny film z filmów 
Oczywiście, nie. Alternatywę dla tej formuły stanowi film montażowy, którego twórca posługuje się wyłącznie archiwaliami z epoki: unikając inscenizowanych dokrętek i ograniczając autorską ingerencję do operacji dokonywanych na stole montażowym na autentycznym materiale filmowym pochodzącym $z$ danej epoki. $Z$ istotnym zastrzeżeniem, iż samo poprzestawanie twórcy filmu na autentycznych archiwaliach bynajmniej nie jest warunkiem wystarczającym, by można było mówić o wyeliminowaniu autorskiego przesłania, a tym bardziej o zupełnym wykluczeniu manipulacji.

Spróbujmy w tym miejscu określić kryteria nowego modelu filmu montażowego. Założenia, jakie przyświecały niniejszemu projektowi, dotyczą szerokiego spektrum zagadnień. Omówimy je w perspektywie nowocześnie uprawianej sztuki dokumentu montażowego, łącząc ją z nurtem refleksji historycznej w dwudziestowiecznej humanistyce znanej pod nazwami: nouvelle histoire, new history lub nowa historia. Podejmując ambitne zadanie, jakim jest realizacja współczesnego filmu o historii, nie zapominamy, iż tematyka historyczna egzystuje w zbiorowej świadomości widzów w wielu różnych kontekstach. W tym również pojawia się ona zwłaszcza w kluczu tak zwanej polityki historycznej i w nieznośnie usztywnionym opakowaniu rocznicowo-pomnikowym.

Rocznice były, są i będą. Producenci i realizatorzy filmów historycznych mają prawo wykorzystywać okrągłe daty do tworzenia tego typu okolicznościowych przekazów, włącznie z uruchamianiem stosownych kontekstów ideowych. Nie ma w tym niczego nagannego, choć z drugiej strony - należy mieć świadomość ograniczeń poznawczych, jakie pociąga za sobą historia $z$ jednostronnym adresem i wydźwiękiem ideowo-politycznym ukazywana: „na endecko”, „na lewicowo”, „na marksistowsko”, „na burżuazyjnie”, w wersji „konserwatywnej”, „bogoojczyźnianej”, „podniosłej”, z myślą o wykorzystaniu w dydaktyce szkolnej etc.

Modelowym przykładem, który zamierzamy tu rozpatrzyć, jest współczesny dokument o początkach II Rzeczypospolitej. Nasza niepodległość odzyskana w roku 1918 domaga się dzisiaj ponownej refleksji. Naprzeciw tej potrzebie wychodzi film montażowy grawitujący intencjonalnie w stronę: kroniki, kalejdoskopu, fresku historycznego, względnie panoramy dramatycznych wydarzeń, jakie się wówczas - to znaczy bezpośrednio przed Wielką Wojną, podczas niej i po jej zakończeniu - rozegrały w Europie.

Dlaczego właśnie ten temat i ten okres historyczny? Odpowiedź na tak postawione pytanie wydaje się dość prosta: od pewnego czasu zarówno w Europie Zachodniej (głównie we Francji i w Wielkiej Brytanii), ale także w naszym kraju obserwujemy wzmożone zainteresowanie Wielką Wojną. Ukazują się o niej niezliczone artykuły i publikacje książkowe oraz albumy fotografii, kręci się fabularyzowane seriale telewizyjne, powstają też znakomicie zrobione dokumenty montażowe zawierające wiele nigdy wcześniej przez nikogo niedemonstrowanych zdjęć dokumentalnych, które do tej pory czekały na odkrycie w zbio- 
rach archiwów filmowych: Paryża, Bois d’Arcy, Londynu, Brukseli, Moskwy, Waszyngtonu, Berlina, Wiednia, Pragi czy Amsterdamu.

Rodzime zasoby archiwalne w tym zakresie są nad wyraz skromne i fragmentaryczne. Nie znaczy to, iż nie posiadamy niczego cennego. Rzecz jednak w tym, że inni mają w swoich archiwach filmowych nieporównanie więcej zachowanych rejestracji dotyczących spraw polskich, niż na temat tego okresu naszej historii mamy do dyspozycji my sami - nie tylko pod względem ilościowym, ale także wedle kryteriów jakościowych. Zwiększyła się także w ostatnich latach dostępność do tych unikatowych materiałów zdjęciowych, z których absolutna większość została poddana cyfryzacji[2] i udostępniona w obiegu sieciowym.

Kluczowe pytanie brzmi następująco: czy da się opowiedzieć o odzyskaniu przez Polskę niepodległości w sposób programowo unikający natrętnej patetycznej retoryki? Czy jesteśmy jako odbiorcy skazani na nieznośnie autorytatywny ton „z wysoka”, którego charakterystycznym nośnikiem formalnym staje się - w taki właśnie podniosły sposób napisany i wygłoszony - komentarz zza kadru? Czy alternatywą dla niego ma być wyłącznie obrazoburcze szyderstwo, czy można znaleźć jeszcze inną drogę? Naszym zdaniem - można. Aby mogło się to stać, niezbędna jest jednak nowa formuła narracji.

Cechy będące wyróżnikami tej formuły dają się za pomocą serii przymiotników określić następująco: osobista, subiektywna, racjonalna, krytyczna wobec materiałów i źródeł, realistyczna, sceptyczna w wymowie, wielowątkowa, nieautorytatywna, operująca fragmentem, relacjonująca z dystansu, powściągliwa, antypatetyczna, pozbawiona okolicznościowych odniesień i uwolniona od rocznicowego zadęcia.

Komuś, kto jako widz nawykł przez lata do perswazyjnej presji dokumentów montażowych, film taki może się wydać na pierwszy rzut oka nazbyt wieloznaczny, „niedookreślony”, „pozbawiony jasnej wykładni” i „amorficzny”. Zwłaszcza że liczne materiały z tamtego okresu, jakie znajdują się w posiadaniu na przykład archiwum Gaumont-Pathé w Paryżu, powstawały okazjonalnie i sfilmowane w nich - rozrzucone zarówno w czasie, jak w przestrzeni - epizody same z siebie nie układają się w spójną narrację.

Prezentowany tutaj w dość ogólnym zarysie i hipotetycznym kształcie projekt jest co prawda „niedookreślony” (do kwestii jego wymowy powrócimy jeszcze w dalszym ciągu rozważań), ale bynajmniej nie ,amorficzny”. Jego ekranowa formuła od strony warsztatowej opiera się na połączeniu z sobą dwu rzeczy.

$Z$ jednej strony, film bazuje wyłącznie na autentycznym materiale zdjęciowym $z$ epoki. $W$ tym przypadku rzeczywiście mającym rewelacyjną wartość: archiwalną, historyczną i (co nie bez znaczenia) estetyczną! Świadomie przyjęte przez twórcę takiego filmu ograniczenie

[2] E. Wysocka, Wirtualne ciało sztuki. Ochrona i udostęnianie dzieł audiowizualnych, Narodowe Centrum Kultury, Warszawa 2013; zob. także prze-
Świadectwo

przeszłości glądowy artykuł Tomáša Lachmana Filmové árchivy $w$,digitalnym věku” („Iluminace. The Journal of Film Theory, History and Aesthetics" 2014, nr 1). 
się do czerpania z jednego tylko zbioru źródeł jest atutem, a nie słabą stroną obranej formuły. Sprawia bowiem, że okazuje się ona jasno zdefiniowana przez wspólny mianownik zewnętrznej (francuskiej) perspektywy, z jakiej je niegdyś sfilmowano.

Czerpiąc z niedawno odkrytych, szczęśliwie zachowanych do naszych czasów, archiwalnych materiałów z epoki, nasz dokument nie ulega i nie respektuje ich anachronicznej dzisiaj narracji, lecz sięga po paletę środków montażowych, która umożliwia realizatorowi swobodne posługiwanie się różnymi chwytami narracyjnymi - zarówno utrzymanymi w konwencji kina niemego (diafragma irys, napisy międzyujęciowe), jak i chwytami typowymi dla konwencji dokumentu dźwiękowego. O takiej a nie innej wymowie całości zdecyduje wybór i kombinacja poszczególnych elementów na stole montażowym. Ale nie tylko.

Z drugiej strony, fresk Niepodległość od początku do końca operuje napisami międzyujęciowymi oraz głosem narratora zza kadru. Tu wypada poczynić dość istotne zastrzeżenie. Opowieść nasza programowo unika - tyleż zdradliwej, ile z gruntu fałszywej - formuły komentarza wygłaszanego w patetyczny i autorytatywny sposób. Formuła taka byłaby całkowicie wbrew autorskim zamierzeniom, celom i intencjom. Będzie ona natomiast posługiwać się rodzajem relacji na żywo komentującej to, co oglądamy na ekranie i - uwaga! - nieustannie odnoszącym ów materiał do współczesności. Zabieg ten ma wyrwać oglądane obrazy, postaci i wydarzenia historyczne z ram konwencjonalnej ilustracji z kart podręcznika historii i uczynić je przedmiotem refleksji dzisiejszego widza.

Głębszy sens całości, a także wrażenie emocjonalne, jakie ma ona wywołać - będą wynikać $\mathrm{z}$ umiejętnego połączenia dwóch nurtów narracji. Same obrazy filmowe sprzed stu lat kryją w sobie ładunek autentyczności, ale - rzutowane jeden po drugim - nie wychodzą poza strumień niepowiązanych z sobą odrębnych epizodów. Aby je związać, konieczny jest drugi komplementarny względem pierwszego nurt ekranowej narracji: głos komentatora dochodzący zza kadru. On także nie stanowi jakości samoistnej. Stąd w naocznej lekturze, poza czasoprzestrzenią ekranu, jego tekst może się wydać dość niespójny, a nawet miejscami chaotyczny.

Jak zwykle w takich przypadkach bywa, spójność przekazu (nie tylko logiczno-racjonalna i przyczynowo-skutkowa, ale także emocjonalna) osiągnięta zostanie dopiero na stole montażowym, gdy poszczególne obrazy spotkają się i połączą: z sobą nawzajem i z komentarzem na ich temat, a całość filmu zostanie wzbogacona o efekty dźwiękowe i muzykę.

Istnieje oczywiście podstawowy problem każdego, a nie tylko tego, filmu w postaci „braku mocnego pomysłu”. Pomysł filmu Niepodległość polega na złamaniu tradycyjnej, mającej za sobą długą historię, konwencji filmu montażowego, która $z$ reguły zmierza w stronę „jedynie słusznej” wizji podjętego tematu. Nie jest bowiem tak, że proces odzyskania niepodległości w roku 1918 został już wcześniej całkowi- 
cie rozpoznany przez filmowców-dokumentalistów i wszystko o nim wiadomo. Co ważne, wielce złożonej problematyce $-\mathrm{z}$ takim trudem wywalczonej i zdobytej niegdyś - niepodległości od bardzo dawna zagraża uwikłanie w rozmaite schematy i abstrakcyjną bezduszność "gotowych" formułek.

Dystans stulecia, jakie upłynęło od tamtych wydarzeń, sprawia, że ujęcia szkolno-podręcznikowe niemal całkowicie wyparły empatię dzisiejszych generacji wobec tego, co było udziałem jej przodków. Charakter materiału filmowego spotyka się tutaj z „egzotyką” naszego własnego świata wobec tamtej - mało znanej współcześnie żyjącym pokoleniom - rzeczywistości. Droga do wolności i narodziny II Rzeczypospolitej były procesem trudnym i bardziej złożonym, niż się obecnie sądzi. Niewiele brakowało, a Polski jako niepodległego państwa w ogóle by nie było.

W zachowanym dokumencie historycznym rzeczą o podstawowym znaczeniu jest kwestia, kto filmuje (sfilmował) dany materiał archiwalny. Widz tego nie wie i nie musi wiedzieć. Twórca filmu montażowego powinien jednak na własny użytek ową kwestię rozszyfrować i - o ile to tylko możliwe - rozpoznać. W tekście filmowym, jaki stanowi każdy bez wyjątku zapis kinematograficzny, zapisanych zostało (czy, jak kto woli, odfotografowało się) mnóstwo cennych informacji. Jedną z najważniejszych stanowi wirtualny nadawca (operator, realizator etc.), który zarówno dla historyka, jak i dla filmowca wykorzystującego do swoich celów takie źródło staje się podmiotem domyślnym i zadaniem badawczym wymagającym uważnej rekonstrukcji.

Najczęściej ów wirtualny nadawca - w czasach i okolicznościach, o jakich mówimy - jest dla nas kimś anonimowym. Zważywszy na odległy czas produkcji oraz sposób pozyskiwania filmowych materiałów kronikalnych w tamtej epoce, nie należy raczej liczyć na to, że kiedykolwiek poznamy imię i nazwisko operatora, który dany obraz zarejestrował. Zapewne na zawsze operator ten pozostanie realizatorem anonimowym. Ale nie znaczy to, że stanowił on w trakcie filmowania byt pozbawiony wszelkich właściwości. Ów anonim - jako osoba filmująca w taki a nie inny sposób to właśnie a nie co innego - staje się bytem znaczącym. Choć anonimowy, nie przestaje być podmiotem dokumentującym określone wydarzenia z myślą o ich uwiecznieniu.

Ważna jest tutaj przede wszystkim sytuacja ekranowa, jaka została zapisana na taśmie, a w niej między innymi: czas i miejsce akcji, identyfikacja postaci, długość ujęcia, sposób jego skadrowania, wyglądy sfilmowanych obiektów, punkt widzenia, okoliczności nakręcenia danego materiału, intencjonalny motyw towarzyszący rejestracji.

W przypadku operatorów francuskich, którzy w latach 1913-1922 pojawiali się z kamerą w tej części Europy, aby coś zarejestrować, daje o sobie znać charakterystyczny efekt obcości, niekiedy wręcz egzotycznej. Widać, że krok po kroku rozpoznają i odkrywają oni nieznaną sobie rzeczywistość (Śląska Cieszyńskiego, Włocławka, Płocka, Krako-

Fenomenologia cudzego widzenia 
wa, Kamieńca Podolskiego, Borysławia, Zakopanego, Warszawy i in.) i uczą się ją rozumieć. Motywem przewodnim wielu z tych rejestracji jest z pewnością jedno: jakiś od dawna zniewolony naród w odległym zakątku Europy Środkowo-Wschodniej dąży z rosnącą determinacją do odzyskania własnej utraconej niepodległości. Świat, w którym znaleźli się z kamerą, jest jednak światem innym niż ich własny.

Neutralność tych rejestracji ma charakter względny i poniekąd paradoksalny. W samym materiale zdjęciowym rozszczepia się ona na dwa aspekty narracji: aspekt subiektywizujący (niezorientowany przybysz z zewnątrz) i obiektywizujący (niezaangażowany obserwator $\mathrm{z}$ kamerą). „Efekt obcości” cudzego oka (mowa przez cały czas o anonimowych operatorach francuskich, którzy nakręcili owe unikatowe zdjęcia niemal stulecie temu) spotyka się tutaj z konsekwentnie utrzymanym od początku do końca sceptycyzmem i osobistą przekorą narratora-komentatora.

Dzięki owemu konsekwentnie utrzymanemu w całym filmie podejściu dojdzie do głosu - niezmiernie rzadko obecny w rodzimym dokumencie montażowym - żywioł zachowanego i umiejętnie wykorzystanego subiektywizmu: połączonego z dystansem obiektywizującym narrację. Jedno i drugie, niczym turbina na spiętrzonej rzece, tworzy układ zasilania filmowej całości. Na naszą własną przeszłość mamy oto okazję spojrzeć niejako „z zewnątrz”, okiem zaciekawionego zagranicznego operatora - dysponując przy tym i operując dystansem „cudzego spojrzenia”.

Efekt ekranowy uzyskany za pośrednictwem komentarza zza kadru zapewni jego odpowiednie wykonanie i wygłoszenie. Ma ono zmierzać w stronę żywej mowy, a unikać tonu autorytatywnego. Warto $\mathrm{w}$ tym miejscu przypomnieć, że autorytatywnie wygłaszany filmowy komentarz zza kadru już w latach 30. (słynne amerykańskie kroniki aktualności „The March of Time”) wytworzył konwencję przekazu powszechnie uważaną w odbiorze za przejaw narracyjnego obiektywizmu. Mówimy tu jednak o pewnym od dawna skonwencjonalizowanym zbiorze chwytów, powołujących do istnienia pewien skonwencjonalizowany sposób przekazu, a nie o czymś, co pozostaje obiektywne samo przez się $\mathrm{z}$ racji tego, że odfotografowało się $\mathrm{w}$ danym materiale zdjęciowym.

Cel tego zabiegu jest oczywisty. Subiektywne spojrzenie francuskiego operatora filmowego i sceptyczne podejście narratora zza kadru - w połączeniu z subiektywnym spojrzeniem widza - powinno wyzwolić na ekranie tak potrzebny dyskurs wokół naszej własnej historii. Na odzyskaną w latach 1918-1919 niepodległość patrzymy z zewnątrz, oglądając ją przez cudzy obiektyw. Niepodległość jako filmowy dokument o nowej Polsce odradzającej się w tamtym okresie ma być właśnie historią widzianą i myślaną przez dyskutujących z sobą autora i widza: jednocześnie przeżywaną $\mathrm{z}$ dystansu i bliską adresatowi jako na nowo wydobyte i odkrywane po latach, zarejestrowane cudzą ręką świadectwa własnej przeszłości. 
W tym stadium rozważań zasadne staje się twierdzenie, iż poetyka nowego dokumentu historycznego czerpie swoją inwencję i właściwy jej pierwiastek innowacyjności nie z jakiegoś pojedynczego, nieznanego wcześniej, wniesionego przez nią elementu, lecz z - niekonwencjonalnie przeprowadzonej - rekonfiguracji układu elementów i czynników dotąd stosowanych w odmienny sposób. Nie sama substancja filmowa zatem jest najważniejsza, lecz filmowa struktura, w jakiej owe elementy zostają umieszczone, znajdując swój nowy sens: w taki, a nie inny sposób zorganizowany i zmontowany przez autora w danym przekazie.

Archiwalne materiały filmowe, $z$ których tworzy się film montażowy, nie są komunikatem oczywistym i jednoznacznym: ani na powierzchni sfilmowanych przed stuleciem zdarzeń, ani w ich strukturze głębokiej obejmującej: czas i miejsce akcji, zdarzenia, osoby, fakty, okoliczności nakręcenia czy intencje filmującego. Każdy z tych materiałów w świetle uważnego rozpoznania okazuje się całostką montażową nacechowaną wieloznacznością i ambiwalencją możliwych odczytań. Pula tych odczytań wyznacza pole autorskiego manewru w procesie ich (re)interpretacji, zmierzającej do wykorzystania danego materiału w nowym filmie. Oczywistość powierzchni danego przedstawienia okazuje się czymś złudnym i pełnym immanentnych sprzeczności. Sytuacja, o której tu mowa, dotyczy nie tylko pojedynczego zapisu filmowego, lecz również całego przekazu.

$\mathrm{Na}$ liście biegunowych przeciwieństw, z jakimi każdorazowo ma do czynienia twórca filmu montażowego o tematyce historycznej, znajdują się następujące opozycje:

$$
\begin{gathered}
\text { przeszłość - historia } \\
\text { czas miniony - teraźniejszość } \\
\text { znane - nieznane } \\
\text { fragmentaryczność - całościowość } \\
\text { subiektywizacja - obiektywizacja } \\
\text { źródłowość - fikcjonalizacja } \\
\text { autentyzm - inscenizacja } \\
\text { monofoniczność - wielogłosowość } \\
\text { autorytatywność - dyskursywność }
\end{gathered}
$$

Żaden twórca filmu montażowego nie uniknie w swej pracy konfrontacji z syndromem wymienionych wyżej przeciwieństw. Ich koincydencja tworzy nieustannie obecne pole oddziaływania. Z jednej strony ogranicza, $\mathrm{z}$ drugiej stymuluje proces powstawania i tworzenia danego przekazu. Jego autor nigdy nie działa w społeczno-kulturowej próżni. Postępując tak a nie inaczej z cudzym materiałem i ze swoim filmem - za pomocą serii ruchomych obrazów wizualnych bądź audiowizualnych - odkrywa i projektuje przeszłość, rzutując ją na czas dzisiejszy i zamieniając w określoną narrację historyczną.

Dokument montażowy o historii nabiera wartości, jeśli spełnia swą podstawową funkcję: ma odkrywczo poinformować kogoś o przeszłości. Suspens historyczny, z jakim mamy tu do czynienia, polega na odkrywaniu faktów nieznanych bądź na korygowaniu czegoś, co 
istnieje od dawna w zbiorowej świadomości jako ustalone wyobrażenie danego fragmentu historii. Z tego względu szczególnie cenną wartość społeczno-kulturową wnoszą z sobą do debaty publicznej finezyjnie pomyślane i umiejętnie zrealizowane ujęcia nieoczywiste i kontrowersyjne. Pobudzają one bowiem i od nowa wywołują okołohistoryczny dyskurs, który na dobrą sprawę ma się toczyć nieustannie.

Kreując i oferując określoną wizję ekranową tego, co się niegdyś wydarzyło, twórca dokumentu montażowego powinien nieustannie mieć na uwadze widza. Rodzaj autorskiej empatii i słuchu na adresata przekazu ciągle spotyka się podczas pracy nad filmem $z$ jego własnym, nieuchronnie subiektywnym, autorskim podejściem do tematu. Koniecznością staje się w tej sytuacji zrozumienie odbiorcy: świadomość, kim jest, jakie ma przyzwyczajenia, co wie, a czego jeszcze nie wie, jaki jest jego system wartości. Wprojektowany w dany przekaz wirtualny odbiorca przez swą symboliczną obecność w nim organizuje proces percepcji, stanowiąc układ odniesienia w relacji $\mathrm{z}$ twórcą filmu.

Analogicznie przedstawia się zagadnienie tzw. obrazu autora, czyli autokreacji twórcy filmu zaprojektowanej w formie wirtualnego nadawcy przekazu. Autor wewnętrzny zawsze stanowi znakową emanację określonego poglądu i spojrzenia na prezentowaną przeszłość. Może on być kimś przywiązanym do z góry powziętej wykładni: fanatycznie przekonanym o jedynie słusznej wizji ukazywanych przez siebie wydarzeń. Bądź też, całkiem przeciwnie, cierpliwie poszukiwać po latach (bądź wiekach) sensownego, racjonalnego ich wyjaśnienia - bywa że na przekór wersji dotąd panującej.

Może również wątpić w istnienie jednego tylko „odpowiedniego” klucza do pojmowania tego, co się niegdyś wydarzyło. Ten właśnie rodzaj podejścia do historii, z jakim mamy do czynienia w montażowym filmie historycznym, jest dzisiaj o wiele częstszy niż dawniej. Za każdą ze wskazanych ewentualności stoi nie tylko jego osobista postawa i rola: apologety, fanatyka, doktrynera, agitatora, propagandysty, manipulatora, badacza, sceptyka, historiozofa, mitotwórcy, mitoburcy, hagiografa, apokryfisty itp.). Dochodzi do tego coś więcej, a mianowicie pewien model porozumienia i relacji łączącej go $\mathrm{z}$ widzem, a wraz z nim - sposób traktowania przeszłości i historii w kontekście jej psychospołecznych związków z określonym tu i teraz.

Dokument montażowy o historii stanowi rodzaj spotkania dwu świadomości - autorskiej i odbiorczej - na temat tego, co się niegdyś wydarzyło. Jednym z wariantów takiego spotkania jest wspólne odkrywanie prawdy o przeszłości. Postawa racjonalna otwiera przestrzeń dla dyskursu i wymiany myśli, poszerza sferę publicznej debaty. Spotkanie, do jakiego wówczas dochodzi, okazuje się z reguły pełną napięć konfrontacją. Nie można tych sprzeczności ominąć. Można natomiast zaprząc ich biegunową energię do wspólnych celów, prowadząc w ramach danej konstrukcji grę o uzyskanie optymalnego efektu poznawczego i artystycznego. W tym sensie dokument historyczny pełni ważką rolę społeczną, kształtując określone wyobrażenie przeszłości, o której opowiada. 
Konkluzja powyższych rozważań zmierza do twierdzenia, iż każde posłużenie się archiwalnym materiałem filmowym nieuchronnie angażuje i uruchamia udział „cudzej mowy”, „cudzego obrazu” i „cudzego spojrzenia”. Naiwnością byłoby sądzić, że możliwy jest film z filmów całkowicie uwolniony od jakiegokolwiek przesłania. Podobnie jak nie można takiego filmu uwolnić od fragmentaryczności i subiektywizmu użytych do jego budowy elementów obdarzonych własnym znaczeniem. Można i należy natomiast dążyć do takich jego form, które będą wolne od udziału arbitralnej manipulacji materiałem zdjęciowym, choćby nawet wynikała ona z najsłuszniejszych pobudek i najszlachetniejszych przesłanek, jakimi kierował się autor filmu.

Aby tak się stało, konieczne jest spełnienie szeregu warunków. Jednym z nich - być może najważniejszym - pozostaje dyskursywny charakter konstrukcji filmu montażowego, w którym daje o sobie znać wielogłosowość zawartego w nim przesłania, zaprojektowana przez twórcę i odzywająca się echem w świadomości widza. To właśnie stanowi warunek sine qua non głębokiego historyzmu, ku któremu powinna zmierzać ambitnie zaprojektowana współczesna formuła filmu montażowego nowej generacji. 